\title{
Gibberellic Acid Utilization in Seeds and Plants of Beans: Effect on Growth and Seeds Physiological Quality
}

\author{
Lanes B. A. Jaques ${ }^{1}$, Ivan R. Carvalho ${ }^{1}$, Vinícius J. Szareski ${ }^{1}$, João R. Pimentel ${ }^{1}$, Cristian Troyjack ${ }^{1}$, \\ Simone M. Dellagostin ${ }^{1}$, Mayara T. Mendonça ${ }^{2}$, Tiago C. da Rosa ${ }^{1}$, Francisco A. Villela ${ }^{1}$, Velci Q. de Souza ${ }^{3}$, \\ Tiago Z. Aumonde ${ }^{1} \&$ Tiago Pedó $^{1}$ \\ ${ }^{1}$ Federal University of Pelotas, Capão do Leão, Rio Grande do Sul, Brazil \\ ${ }^{2}$ Federal University of Santa Maria, Santa Maria, Rio Grande do Sul, Brazil \\ ${ }^{3}$ Federal University of Pampa, São Gabriel, Rio Grande do Sul, Brazil \\ Correpondence: Ivan R. Carvalho, Federal Unviersity of Pelotas, Capão do Leão, Rio Grande do Sul, Brazil. \\ E-mail: carvalho.irc@gmail.com \\ Cristian Troyjack, Federal Unviersity of Pelotas, Capão do Leão, Rio Grande do Sul, Brazil. E-mail: \\ cristiantroyjack@hotmail.com
}

Received: July 9, 2018

Accepted: November 23, 2018

Online Published: January 15, 2019

doi:10.5539/jas.v11n2p541

URL: https://doi.org/10.5539/jas.v11n2p541

\begin{abstract}
The growth regulators from gibberellins, when applied on plants, might improve physic and physiological features, stimulate cell division and elongation, this study aimed at evaluating the influence of gibberellic acid doses applied exogenously on bean crop through seed treatment, and analyzing its effects on morphological attributes of seedlings and physiological quality of the seeds produced. The experimental design was completely randomized design, with treatments corresponding to the doses: zero (distilled water only), 50, 100 and $200 \mathrm{mg}$ $\mathrm{L}^{-1}$, arranged in four replicates. The use of gibberellic acid in bean seeds did not result in changes on the number of leaves, leaf area, dry mass of leaves and stem. Applications of foliar gibberellic acid potentiated stem height and root dry mass of seedlings.
\end{abstract}

Keywords: Phaseolus vulgaris L., crop management, seed production, plant physiology

\section{Introduction}

Beans (Phaseolus vulgaris L.) present great importance for Brazilian agriculture in the social and economic extent, where more than 3.2 million hectares were grown in the 2017/2018 agricultural year, in three cultivation periods (CONAB, 2018). It is characterized as one of the main leguminous, and daily relates to majority of Brazilians' diet due to its high protein and energetic value (Moreira et al., 2017). Brazil is the main producer and consumer in the world, with per capita annual consumption of $16 \mathrm{~kg}$ of grains (Barbosa et al., 2010). However, the national yield is low, being around $465 \mathrm{~kg} \mathrm{ha}^{-1}$ in the 2016/2017 agricultural year (CONAB, 2017). It is due to low utilization of certified seeds and investments in genetic breedingfor specific micro regions, number of genotypes and precarious studies regarding management practices (Ribeiro et al., 2008).

Bean plants feature low first pod insertion height, which difficult mechanized harvest and increase losses (Marcos Filho et al., 2009; Silva et al., 2008). In order to minimize losses and increase yield per unit area, some researches are being carried out aiming at the development of highly yielding genotypes, which depend on genetic breeding, as well as the improvement of morphological and physiological traits such as harvesting rate and photosynthetic efficiency (Buzello, 2010; Carvalho et al., 2016).

The available genotypes present good amplitude regarding sowing timing, plant architecture and favorable vegetative growth for increased grain and seed yield, however, increments in several other desirable agronomic attributes are still sought (Souza et al., 2010; Szareski et al., 2018). In this relation, researchesapproaching the use of growth regulators have the purpose of modifying plants architecture and improving practices and management for crops of interest (Lana et al., 2009). Growth regulators modify the plant morphologically in a way that growth and development are either promoted or inhibited (Kappes et al., 2011). The regulators may be composed of indolebutyric acid, kinetin and gibberellic acid, which act to increase plant growth and 
development, increase cell wall extensibility, and absorb water and nutrients (Vieira \& Castro, 2002; Taiz \& Zeiger, 2013).

Giberellin sconstitute a group of plant hormones that act in the elongation and cell division (Buchanan, 2015), which are synthesized in the form of gibberellic acid (Carraher Jr. et al., 2010). This regulator's concentration and plant tissues sensitiveness to this compound determine plants response regarding growth and development (Espindula et al., 2010). Thus, the exogenous application of gibberellic acid in bean plants may directly influence plant growth, as well as its morphological and reserve attributes (Troyjack et al., 2017). Considering that growth regulators from gibberellins, when applied on plants, might improve physic and physiological features, stimulate cell division and elongation, this study aimed at evaluating the influence of gibberellic acid doses applied exogenously on bean crop through seed treatment, and analyzing its effects on morphological attributes of seedlings and physiological quality of the seeds produced.

\section{Material and Methods}

The trials were conducted in the Campus of the Federal University of Pelotas, under coordinates $31^{\circ} 52^{\prime} \mathrm{S}$ and $52^{\circ} 21^{\prime} \mathrm{W}$. In order to determine the influence of exogenous gibberellic acid application $\left(\mathrm{GA}_{3}\right)$ on bean crop through seed treatment and foliar spraying, two experiments were performed:

In experiment $I$, the influence of different $\mathrm{GA}_{3}$ doses on morphological attributes of seedlings was verified. The application was carried out directly in the seeds with the aid of a graduated pipette. These seeds were placed in transparent polyethylene bags with capacity for $1.0 \mathrm{~kg}$ for homogenization and product adhesion. The doses used were zero (distilled water only), 50, 100 and $200 \mathrm{mg} \mathrm{L}^{-1}$. After 5 minutes, 20 seeds were arranged to germinate in rolls formed by three sheets of germitest paper, moistened with distilled water in the proportion of 2.5 times the dry mass of the paper. After the linear arrangement of the seeds on the sheets, the rolls formed were directed to germination chamber type B.O.D. at constant temperature of $25^{\circ} \mathrm{C}$. On the eighth day after sowing, the following characters were measured: number of leaves (results expressed in units), plant height (distance between base and stem apex, results in centimeters), leaf area (obtained through Licor meter LI-3100 ${ }^{\circledR}$, results expressed in square meters), dry mass of leaf, stem and root (obtained by drying the seedlings in oven with forced air ventilation at $70^{\circ} \mathrm{C}$ until constant mass, with subsequent mass measurement in grams).

In the experiment $I I$, it was evaluated the influence of exogenous $\mathrm{GA}_{3}$ application through foliar spraying on seeds physiological quality. The seeds were sown in polyethylene pots of 20 liters of capacity, with substrate composed of soil from the A1 horizon of a Planosol Haplic Eutrophic Solodic (Streck et al., 2008). The corrections and fertilization were performed according the technical regulations (CQFS RS/SC, 2004). Bean plants at V2 phenological stage were submitted to aerial application of gibberellic acid $\left(\mathrm{GA}_{3}\right)$ at doses zero (distilled water only), 50, 100 and $200 \mathrm{mg} \mathrm{L}^{-1}$. Seeds were manually harvested with approximately $16 \%$ of humidity. After, they were dried in oven with forced air circulation at $35^{\circ} \mathrm{C}$, and dried in a steady dryer until homogeneous humidity of $12 \%$. The seeds were manually harvested and stored in a cold room with average temperature of $15{ }^{\circ} \mathrm{C}$ and relative humidity of $60 \%$. On this occasion, the following characters were measured:

First Germination Counting (FGC): carried out along the germination test, being counted at five days after sowing, according to the Rules for Seed Analysis (MAPA, 2009). The results were expressed as percentage of normal seedlings. The germination test was performed through four samples of 50 seeds, arranged to germinate in rolls formed by three sheets of germitest paper, moistened with distilled water in the proportion 2.5 times the dry mass of the paper. After the linear arrangement of the seeds on the sheets, the rolls formed were later transferred to a germination chamber type B.O.D. at $25{ }^{\circ} \mathrm{C}$. The evaluations were performed nine days after sowing, whit results expressed as percentage of normal seedlings (MAPA, 2009).

Aerial Part Length (APL) and Length of Primary Root of Seedlings (RL): verified from four samples of 10 seedlings, at the end of germination test. The length of aerial part was obtained by the distance between primary root base and aerial part apex, determining the length of primary root through the distance between the extremities of this structure, results in centimeters.

Root Dry Mass (RDM) and Dry Mass of Aerial Part (DMAP): Achieved through the mass of 10 seedlings at the end of germination test, these seedlings were packed in brown paper envelopes and subjected to forced ventilation drying under temperature of $70^{\circ} \mathrm{C}$ for 72 hours, root and shoot dry mass were obtained separately for each structure, results in centimeters $\left(\mathrm{g}\right.$ tissue $\left.\mathrm{e}^{-1}\right)$.

The experimental design was completely randomized design, with treatments corresponding to the doses: zero (distilled water only), 50, 100 and $200 \mathrm{mg} \mathrm{L}^{-1}$, arranged in four replicates. The data were submitted to the statistical model assumptions, and then, to analysis of variance by the $\mathrm{F}$ test at $5 \%$ of probability, separately for 
each experiment. When checking the significance, the traits were submitted to the diagnosis of the highest significant polynomial degree by the $t$ test at $5 \%$ of probability. Furthermore, the linear regression was performed for each trait in order to identify the tendencies for the quantitative levels tested.

\section{Results and Discussion}

The analysis of variance revealed significance at $5 \%$ of probability for stem height and root dry mass of seedlings submitted to $\mathrm{GA}_{3}$ applied on the seeds (Table 1), and root length, dry mass of aerial part and root dry mass of seedlings when $\mathrm{GA}_{3}$ was applied in the plants (Table 2). The traits number of leaves, leaf area, leaf dry mass, stem dry mass, were not significantly influenced by the treatments with $\mathrm{GA}_{3}$ applied via seed (Table 1). The length of aerial part, first germination counting, germination and emergence atfield presentedno significance for physiological quality of the seeds produced.

Table 1. Summary of the analysis of variance with mean squares for number of leaves (Nl), stem height (Sh), leaf area (La), leaf dry mass (DMl), stem dry mass (DMs) and root dry mass (DMr) of beans in response to different $\mathrm{GA}_{3}$ doses applied in the seeds

\begin{tabular}{|c|c|c|c|c|c|c|c|}
\hline \multirow{3}{*}{ F.V. } & \multirow{3}{*}{$\mathrm{DF}$} & \multicolumn{6}{|c|}{ Mean Squares } \\
\hline & & \multicolumn{6}{|c|}{ Growth traits } \\
\hline & & $\mathrm{Nl}$ & $\mathrm{Sh}$ & $\mathrm{La}$ & DMl & DMs & $\mathrm{DMr}$ \\
\hline Doses & 3 & $0.1111^{\mathrm{ns}}$ & $149.81^{*}$ & $183.40^{\mathrm{ns}}$ & $0.0030^{\mathrm{ns}}$ & $0.0023^{\mathrm{ns}}$ & $0.0014^{*}$ \\
\hline Replicates & 2 & 0.0833 & 8.46 & 116.75 & 0.0008 & 0.0022 & 0.00009 \\
\hline Residue & 6 & 0.1944 & 5.45 & 131,12 & 0.0017 & 0.0009 & 0.0001 \\
\hline Average & - & 3.16 & 17.38 & 47.65 & 0.20 & 0.11 & 0.081 \\
\hline CV (\%) & - & 13.92 & 13.44 & 24.03 & 20.31 & 27.55 & 14.90 \\
\hline
\end{tabular}

Note. Mean squares: ${ }^{*}$ and ns: significant at $5 \%$ of probability and non-significant, respectively; CV: coefficient of variation; FV: factor of variation.

Table 2. Summary of the analysis of variance with mean squares for length of aerial part (Lap), root length (Rl), dry mass of aerial part (DMap), root dry mass (DMr), first germination counting (FCG), germination (G), and emergence at field $(\mathrm{EF})$ in response to different $\mathrm{GA}_{3}$ doses through leaf application in the matrix plant

\begin{tabular}{|c|c|c|c|c|c|c|c|c|}
\hline \multirow{3}{*}{ F.V. } & \multirow{3}{*}{$\mathrm{DF}$} & \multicolumn{7}{|c|}{ Mean Square $^{(1)}$} \\
\hline & & \multicolumn{7}{|c|}{ Qualitytraits } \\
\hline & & Lap & $\mathrm{Rl}$ & DMap & $\mathrm{DMr}$ & FGC & $\mathrm{G}$ & $\mathrm{EF}$ \\
\hline Doses & 3 & $2.3646^{\mathrm{ns}}$ & $3.1457^{*}$ & $0.0156^{*}$ & $0.0019^{*}$ & $45.33^{\mathrm{ns}}$ & $33.00^{\mathrm{ns}}$ & $20.25^{\mathrm{ns}}$ \\
\hline Replicates & 3 & 1.1526 & 0.1089 & 0.0004 & 0.00008 & 50.66 & 30.33 & 46.91 \\
\hline Residue & 9 & 0.6315 & 0.7994 & 0.0008 & 0.0001 & 32 & 21.44 & 23.8 \\
\hline Average & - & 10.84 & 11.66 & 0.43 & 0.14 & 80 & 86 & 87.12 \\
\hline CV (\%) & - & 7.32 & 7.66 & 6.54 & 7.74 & 7.07 & 5.36 & 5.60 \\
\hline
\end{tabular}

Note. ${ }^{(1)}$ Mean squares: ${ }^{*}$ and ns: significant at $5 \%$ of probability and non-significant, respectively; CV: coefficient of variation; FV: factor of variation.

The trait stem height adjusted to the quadratic model with coefficient of determination of $R^{2}=0.77$ (Figure $1 \mathrm{~A}$ ). Increased stem height was observed due to increments of $\mathrm{GA}_{3}$ doses, with maximum efficiency through the dose of $150 \mathrm{mg} \mathrm{L}{ }^{-1}$. However, the lower stem height was obtained in the absence of this compound application. The increase of stem height in response to higher $\mathrm{GA}_{3}$ concentrations are due to the use of regulators that act as chemical signals through receptors, which trigger cellular changes, modifying the dimensions of plant organs, where gibberellic acid applied via seeds potentiated seedling performance, accelerating emergence speed and improving plant productive potential (Lima-Brito et al., 2006).

Research by Vasconcelos et al. (2015) determined that the effect of gibberellic acid application on seedling emergence were dependent on the use of higher concentrations, which provided increments in germination percentage, emergence speed index and averagetime for seed germination in relation to absence of gibberellic acid. The trait root dry mass (Figure $1 \mathrm{~b}$ ) adjusted to the quadratic polynomial model: $\hat{Y}=0.0723+0.0006 \mathrm{x}-$ $3 \mathrm{E}-06 \mathrm{x}^{2}$, revealing coefficient of determination of $\mathrm{R}^{2}: 0.76$, being possible to increment this trait through the 
dose of $100 \mathrm{mg} \mathrm{L}^{-1}$, which resulted in greater accumulation of mass of roots in response to application of this compound.
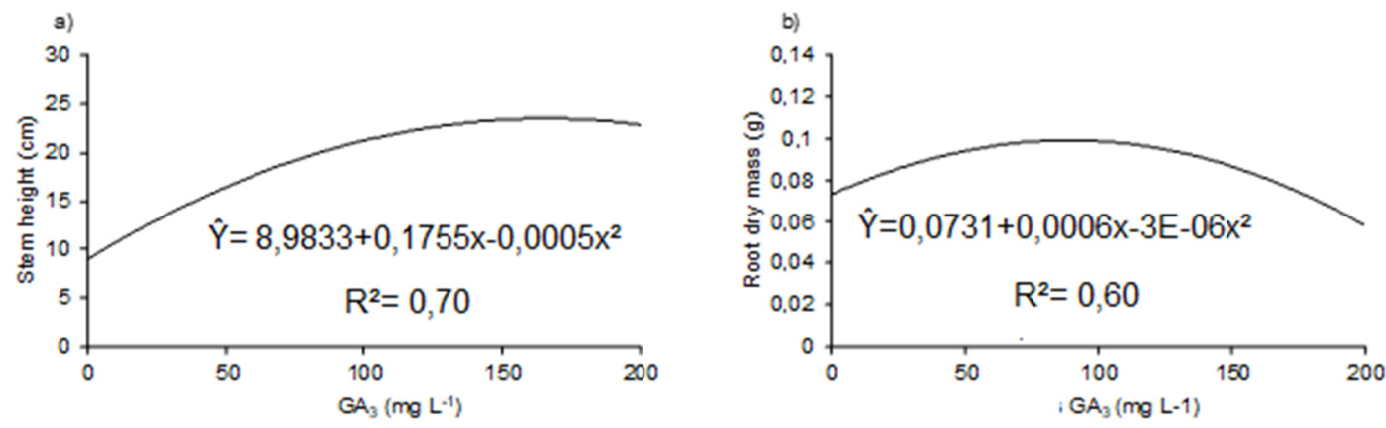

Figure 1. Stem height (a) and root dry mass (b) of bean seedlings subjected to different doses of gibberellic acid applied in the seeds
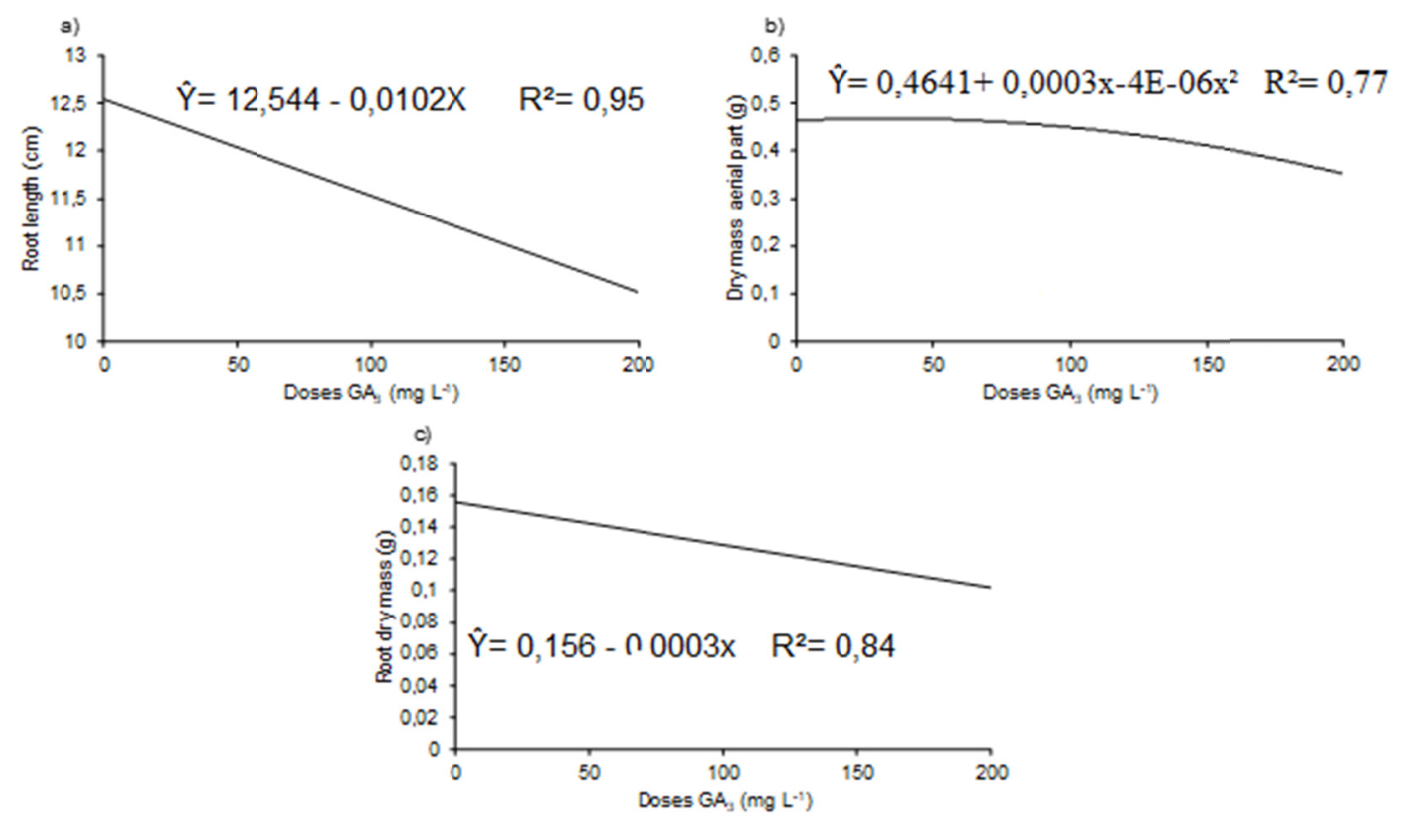

Figure 2. Root length (a), dry mass of aerial part (b) and root dry mass (c) of bean seedlings originated from seeds produced by plants submitted to different doses of gibberellic acid application

Researches definethat the efficiency of $\mathrm{GA}_{3}$ via seed treatment may improve seedling initial growth, whereby gibberellin causes the primary root to rupture tissuesand reduce growth, as well as the endosperm or seed tegument, while cytokinins and auxins complement the effects of gibberellins and induct cell division and proportion of root and aerial part of seedlings (Crozier et al., 2001; Taiz \& Zeiger, 2013).

Regarding the physiological quality of seeds produced when $\mathrm{GA}_{3}$ was applied via leaf, it was observed that root length of seedlings (Figure 2a) and root dry mass (Figure 2c) were adjusted to the linear model with high coefficient of determination. For this genotype, there was a decrease in seedlings length due to increments on $\mathrm{GA}_{3}$ doses. The dry mass of seedlings aerial part presented similar behavior with decrease (Figure $2 \mathrm{~b}$ ) and adjustment to the quadratic model (Figure $2 b$ ), with coefficient of determination $\mathrm{R}^{2}=0.76$. Thereby, increasing concentrations of $\mathrm{GA}_{3}$ did not result in greater dry matter allocation in the seedlings, and did not result in superiority for seedling initial performance.

The reduction in quality of the produced seeds due to increments of $\mathrm{GA}_{3}$ concentration allows to infer that plants submitted to higher $\mathrm{GA}_{3}$ doses, possibly result in lower allocation of carbon in the seeds, when compared to the total dry matter allocated in the plant, which depends on seeds physiological potential (Troyjack et al., 2017). 
The lowest magnitude of this trait is related to modificationsin the relation of plant drains during seed production period, which is related to growth, dry matter of seed and total in the plant (Benincasa, 2003).

The gibberellins are responsible for several physiological functions essentials for developing superior plants. They improve reserves mobilization in the seeds, improve germination and promote stem elongation in some species, may act on leaf expansion, floral induction and anthocyanin biosynthesis (Garcia-Martinez et al., 1987; Van Huizen et al., 1997). Studies demonstrate that exogenous GA $_{3}$ application in plants may inhibit enzymatic activities determinant for nitrogen metabolism, mainly through nitrate-reductase and glutamine synthetase (Goupil et al., 1997).

Due to the use of $\mathrm{GA}_{3}$ applied directly to bean seeds, there are positive effects for seedling stem height, which is an extremely important feature for crop establishment. However, the application of $\mathrm{GA}_{3}$ in the plants had no effects in the quality of seeds produced, but it increased aerial part dry mass, root length and dry mass of roots.

\section{Acknowledgements}

To Coordenação de Aperfeiçoamento de Pessoal de Nível Superior (CAPES) and the Conselho Nacional de Desenvolvimento Científico e Tecnológico (CNPq) for the scholarship granted.

\section{Conclusions}

The use of gibberellic acid in bean seeds did not result in changes on the number of leaves, leaf area, dry mass of leaves and stem. Applications of foliar gibberellic acid potentiated stem height and root dry mass of seedlings.

\section{References}

Abrantes, L. F., Sá, E. M., Souza, D. C. L., Silva, P. M., Simidu, M. H., Andreotti, M., ... Arruda, N. (2011). Uso de reguladores de crescimento em cultivares de feijao de inverno. Pesquisa agropecuária. Trop., Goiania, 41(2), 148-154.

Barbosa, G. F., Nascimento, M. S., Buzzetti, S., \& Freddi, O. S. (2011). Nitrogênio em cobertura e molibdênio foliar no feijoeiro de inverno. Acta Scientiarum, 33(4), 665-670.

Benincasa, M. M. P. (2003). Análise de Crescimento de Plantas (noções básicas) (p. 41). Jaboticabal, Funep.

Buchanan, B. B., Gruissem, W., \& Jones, R. L. (2015). Biochemistry and molecular biology of plants (2nd ed., p. 1280). Rockville, American Society of Plant Physiologists.

Buzzello, L. G. (2010). Uso de reguladores no controle do crescimento e no desempenho agronômico na cultura da soja cultivar CD 214 RR (Dissertação, Universidade Tecnológica do Paraná).

Carraher Jr., C. E., Carraher, S. M., \& Stewart, H. H. (2010). Metal-containing polymer structures for enhanced seed germination and plant growth. Advances in Environmental Biology, 4(1), 108-116.

Carvalho, I. R., Nardino, M., Ferrari, M., Pelegrin, A. J., Demari, G., Szareski, V. J., ... Maia, L. C. (2016). Genetic variability among common black bean (Phaseolus vulgaris L.) accessions in southern Brazil. Aust $J$ Crop Sci, 10, 1474-1483. https://doi.org/10.21475/ajcs.2016.10.10.p7786

Catro, P. R. C., Cato, S. C., \& Vieira, E. L. (2005). Biorreguladores e bioestimulantes em fejoiro. In A. L. Fancelli, \& D. Dourado-Neto (Eds.), Feijão irrigado: Tecnologia \& produção (pp. 54-62). Piracicaba: ESALQ.

CONAB. (2017). Acompanhamento da safra brasileira de graos (V4, Safra 2016/2017, N12, Décimo Segundo Levantamento).

Crozier, A., Kamiya, K., Bishop, G., \& Yokota, T. (2001). Biosynthesis of hormones and elicitor molecules. In B. B. Buchanan, W. Gruissem, \& L. J. Russel (Eds.), Biochemestry Molecular Biology of Plants (pp. 850-929). Courier Companies Inc., Philadelphia, USA.

Dubal, I. T. P., Koch, F., Szareski, V. J., Pimentel, J. R., Carvalho, I. R., Nardino, M., ... Pedo, T. (2017). Attributes of growth, physiological quality and isoenzymatic expression of common bean seeds produced under the effect of gibberellic acid. Australian journal of Crop Science, 11, 1116-1122. https://doi.org/ 10.21475/ajcs.17.11.09.pne531

Espindula, M. C., Rocha, V. S., Souza, L. T. de, Souza, M. A. de, \& Grossi, J. A. S. (2010). Efeitos de reguladores de crescimento na elongação do colmo de trigo. Acta Scientiarum. Agronomy, 32, $109-116$. https://doi.org/10.4025/actasciagron.v32i1.943 
Garcia-Martinez, J. L., Sponsel, V. M., \& Gaskin, P. (1987). Gibberellins in developing fruits of Pisum sativum cv. Alaska: Studies on their role in pod growth and seed development. Planta, 170, 130-137. https://doi.org/ 10.1007/BF00392389

Kappes, C., Arf, O., Arf, V. M., Gitti, C. D., \& Alcade, M. A. (2011). Uso de Reguladores de crescimento no desenvolvimento e produção de crotalária. Pesquisa Agropecuária, 41(4), 508-518. https://doi.org/10.5216/ pat.v41i4.10768

Lana, A. M. Q. (2009). Aplicação de reguladores de crescimento na cultura do feijoeiro. Bioscience Journal, 25(1), 13-20.

Leite, V. M., Rosolem, C. A., \& Rodrigues, J. D. (2003). Gibberellin and cytokinin effects on soybean growth. Scientia Agricola, 60(3), 537-541. https://doi.org/10.1590/S0103-90162003000300019

Lima-Brito, A., Campos, V. C. A., Santana, J. R. F., \& Dornelles, A. L. C. (2006). Efeito do ácido giberélico (GA3) na emergência de plantulas de Annona crassiflora Mart., Annona squamosa L. e Annona muricata L. Magistra, 18(1), 27-33.

MAPA (Ministério da Agricultura, Pecuária e Abastecimento). (2009). Regras para Análise de Sementes (p. 399). Secretaria de Defesa Agropecuária, Brasília, MAPA/ACS.

Matos Filho, C. H. A., Gomes, R. L. F., Rocha, M. M., Freire Filho, F. R., \& Almeida, A. C. (2009). Potencial produtivo de progênies de feijao-caupi com arquitetura ereta de planta. Ciência Rural, 39(2), 348-354. https://doi.org/10.1590/S0103-84782009000200006

Moreira, W. K. O., Oliveira, S. S., Alves, J. D. N., Ribeiro, R. A. dos R., Oliveira, I. A., \& Sousa, L. A. S. de. (2017). Evolução da produtividade do feijão-caupi para os principais produtores do nordeste paraense no período de 2000 à 2014. Nucleus, 14(1).

Ribeiro, N. D., Cargnelutti Filho, A., Poersch, N. L., Jost, E., \& Rosa, S. S. (2008). Genetic progress in traits of yield, phenology and morfology of common bean. Crop Breeding and Applied Biotecnology, 8(3), $236-242$. https://doi.org/10.12702/1984-7033.v08n03a08

Silva, C. O., Gomes, J. C., Costa, N. M. B., Andrade, N. J., \& Minim, V. P. R. (2006). Caracterização nutricional de feijão (Phaseolus vulgaris L.) após processamento térmico. Revista CERES, 528-532.

Silva, R. P., Reis, L. D., Reis, G. N., Furlani, C. E. A., Lopes, A., \& Cortez, J. W. (2008). Desempenho operacional do conjunto trator-recolhedora de feijao. Ciência Rural, 38(5), 1286-1291. https://doi.org/ 10.1590/S0103-84782008000500013

Souza, C. A., Coelho, C. M. M., Stefen, D. L. V., Sachs, C., \& Figueiredo, B. P. (2010). Atributos morfométricos e componentes da produção do feijoeiro sob efeito de redutores de crescimento. Cientifica, Jaboticabal, $38(1), 030-038$.

Szareski, V. J., Carvalho, I. R., Demari, G. H., Pelissari, G., Pelegrin, A. J., Barbosa, M. H., ... Aumonde, T. Z. (2018). Path analysis applied to agronomic traits of contrasting growth habit soybeans. Aust J Crop Sci, 12, 531-538. https://doi.org/10.21475/ajcs.18.12.04.pne608

Szareski, V. J., Carvalho, I. R., Kehl, K., Levien, A. M., Nardino, M., Dellagostin, S. M., ... Aumonde, T. Z. (2018). Evaluation of the adaptability and stability of wheat genotypes using a phenotypic index of seed vigor. Pesquisa Agropecuária Brasileira, 53(6), 727-735. https://doi.org/10.1590/s0100-204x20180006 00009

Szareski, V. J., Carvalho, I. R., Demari, G. H., Souza, V. Q., Rosa, T. C., Villela, F. A., ... Aumonde, T. Z. (2018). Multivariate index of soybean seed vigor: A new biometric approach applied to the effects of genotypes and environments. Journal of Seed Science, 40(4), 396-406. https://doi.org/10.1590/2317-1545v40n4198333

Taiz, L., \& Zeiger, E. (2013). Fisiologia vegetal (5th ed., p. 954). Porto Alegre: ArtMed.

Van Huizen, R., Ozga, J. A., \& Reinecke, D. M. (1997). Seed and hormonal regulation of gibberellins 20-oxidase expression in pea pericarp. Plant Physiology, 115, 123-128. https://doi.org/10.1104/pp.115.1.123

Vasconcelos, L. H. C., Vendrusculo, E. P., Vasconcelos, R. F., Santos, M. M., \& Seleguini, A. (2015). Utilização de métodos físicos e de fitorreguladores para superação de dormência em sementes de pinha. Revista de Agricultura Neotropical, 2(4), 20-24. https://doi.org/10.32404/rean.v2i4.267

Vieira, E. L., \& Castro, P. R. C. (2002). Ação de stimulate no desenvolvimento inicial de plantas de algodoeiro (Gossypium hirsutum L.). Piracicaba: USP. 


\section{Copyrights}

Copyright for this article is retained by the author(s), with first publication rights granted to the journal.

This is an open-access article distributed under the terms and conditions of the Creative Commons Attribution license (http://creativecommons.org/licenses/by/4.0/). 